\title{
THE EFFICIENCY OF SUCTION DRAIN USAGE IN ARTHROSCOPIC KNEE SURGERY
}

\author{
Oncel Cuneyt, ${ }^{1}$ Ozcan Mert, ${ }^{2}$ Erem Murat, ${ }^{2}$ Copuroglu Cem, \\ Ciftdemir Mert, ${ }^{2}$ Turan Nesrin Fatma ${ }^{3}$
${ }^{1}$ Yücelen Hospital, Department of Orthopaedic Surgery and Traumatology, Muğla, Turkey
${ }^{2}$ Trakya University, Medical Faculty, Department of Orthopaedic Surgery and Traumatology, Edirne, Turkey
${ }^{3}$ Trakya University, Medical Faculty, Department of Biostatistics, Edirne, Turkey

Primljen/Received 27. 08. 2018. god.

Abstract: Aim: The study was designed to investigate the efficiency of suction drain after arthroscopic knee surgery. It is hypothesized that suction drain decreases postoperative hemarthrosis after arthroscopic knee surgery.

Methods: Patients were randomized into two groups. Suction drain was used in Group I and no drain was used in Group II. The groups were compared in terms of rest and activity pain, range of motion, Lysholm and International Knee Documentation Committee (IKDC) scores, patellar shock, need for postoperative knee puncture, amount of drainage, time of hospitalization, and loss of labor. Arthroscopic interventions like meniscectomy, synovectomy, meniscus repair and microfracture were also compared for the amount of patellar shock, need for postoperative knee puncture and amount of drainage.

Results: The difference for activity pain and range of motion between the two groups was statistically nonsignificant. Rest pain improved faster in control group. Lysholm and IKDC scores were improved in both groups but the amount of increase was statistically nonsignificant. The amount of patellar shock was also statistically nonsignificant between the two groups. The amount of patellar shock, need for postoperative knee puncture and amount of drainage were also statistically nonsignifiant for arthroscopic interventions like meniscectomy and synovectomy.

Conclusions: Suction drain application was unnecessary in many situations after arthroscopic knee surgery in this study. Although suction drain usage delayed the recovery from postoperative pain in this study, other parameters of pain were not affected from suction drain usage. Routine usage of a suction drain after arthroscopic knee surgery was not recommended.
Prihvaćen/Accepted 27. 09. 2018. god.

Key words: Suction drain, knee arthroscopy, hemarthrosis, postoperative pain, patellar shock.

\section{INTRODUCTION}

Suction drains are widely used after knee surgery in orthopaedic practice to decrease the amount of postoperative hematoma however benefits of suction drain usage is still controversial $(1,2)$. Suction drain usage is not a routine procedure after arthroscopic knee surgery, and it is a controversial subject $(2,3)$.

It was thought that the postoperative hematoma after arthroscopic knee surgery may irritate the synovium causing postoperative effusion and capsular distension and eventual patient discomfort $(3,4)$. Postoperative complaints, mobilization capacity, hospitalization time and time of occupation loss can change according to amount of hematoma and rehabilitation can be delayed. There is no study in the literature which proves the effect of suction drain usage on postoperative hemarhrosis and effusion after knee arthroscopy. Most of the studies about this subject was performed after anterior cruciate ligament (ACL) reconstruction. There are a few case series about this subject however they are away from explaining the problem $(1,3)$. Therefore we aimed to clarify suction drain usage after arthroscopic knee surgery.

According to our hypothesis suction drain usage after arthroscopic knee surgery decreases postoperative hemarthrosis and subsequent knee effusion and increases postoperative comfort.

\section{MATERIAL AND METHODS}

In this randomized double blind study 113 patients who underwent arthroscopic knee surgery were evaluated. Arthrotomy was needed in three patients du- 
ring operation, therefore these three patients were removed from the study. The patients who were treated for ACL reconstruction were not included to the study. The patients with systemic disorder, bleeding diathesis, history of acute major knee trauma or synovial disorder were also excluded from the study. Institutional review board approval and patient informed consent were obtained for all patients.

The patients were randomly divided into two groups by a computer program. Group 1 (mean age 41.42, 33 male $(60 \%)$ and 22 female $(40 \%))$ included 55 patients with a suction drain and Group 2 (mean age 41.62, 32 male (58\%) and 23 female (42\%)) included 55 patients without a suction drain. The study was designed double blind, meaning that the surgeon and the follow-up physicians were not informed about the drain status of the patients. All patients were operated by the samesurgeon under spinal or general anesthesia. Arthroscopic pump was not used in any of the patients. Standart tourniquet which was inflated to $300 \mathrm{mmHg}$ was used in all operations. Asuction drain (Bicakcilar, Turkey, B-VAK 400 Wound Drainage System 12CH) with an external diameter of $4 \mathrm{~mm}$ was inserted at the end of operation in Group 1. After a compressive dressing was applied from tigh to ankle, the clamp of the drain was opened.

Suction drains were removed $24 \mathrm{~h}$ after the operation and the amount of drainage was noted. The same rehabilitation programme was applied to all patients including active quadriceps strengthening and range of motion increasing exercises, and they were allowed to bear weight as soon as they tolerated.

The patients were controlled four times postoperatively (first day, second and sixth week, and third month). Pain during daily routine activities (climbing upstairs, walking, squatting etc.) of the patients were recorded before and after the surgery and called as routine activity pain. Rest pain of the patients were also recorded before and after the operation and called as rest pain. Preoperative knee range of motion of the patients were measured and compared with postoperative measurements. Severity of pain was evaluated with Visual Analogue Scale (VAS). VAS is a horizontal line divided into ten equal intervals in which zero represents no pain and ten represents the worst pain ever felt. Operative findings and surgical interventions were noted for each patient. The most common surgical interventions were meniscectomy, synovectomy, meniscal repair and subchondral microfracture.

Preoperative and postoperative sixth week and third Lysholm scores (5) and International Knee Documentation (IKDC) 2000 knee evaluation scores (6) of the patients were measured and noted.

Postoperative knee effusion was determined by patellar shock. Patellar shock was graded in four sca- les: Grade 1, some notable fluid, Grade 2, minimally elevated patella, Grade 3, patellar ballottement, and Grade 4, tense knee capsule, unable to compress patella (7). Knee puncture was applied to all Grade 4 and symptomatic Grade 3 patients. The patients who needed postoperative knee puncture and the amount of the fluid (puncture fluid) were noted.

A power analysis was conducted to minimize error and bias. According to post hoc power analysis enrolling 55 subjects in each group would provide an adequate sample size to achieve a power of $>80 \%$ at a $p<0.05$ significance level to detect a difference of ten points in the knee score (Lysholm) improvement and a difference of ten degrees in the knee motion improvement.

The Statistical Package for the Social Sciences for Windows (Version 20, serial 10240642) was used for statistical analysis. Suitability of quantitative data to normal distribution was determined by one sample Kolmogorov Smirnov test.

For normally distributed data variance analysis was used to make comparisons between the groups, and to describe changes in repeated measurements in each group. T-test was used in comparisons of independent groups. For the data that was not normally distributed, Mann Whitney-U test was used to compare groups, Friedman and Wilcoxon two sample tests were used in intra-group comparisons. Yates corrected $\mathrm{X}^{2}$, Fisher's exact $X^{2}$ and KolmogorovSmirnov two sample tests were used in qualitative data. Median (minimum - maximum) and mean value \pm standart deviations were given as descriptive statistics. The level of significance was set at $\mathrm{p}<0.05$.

\section{RESULTS}

The groups were comperable in terms of age and gender ( $\mathrm{p}=0.912$ for age ( $\mathrm{t}$-test for independent groups) and $p=1.000$ for gender (Fisher's exact Chi-Square test). Arthroscopic interventions were summarized in Table 1, and also there was no statistically significant difference between the groups in terms of arthroscopic interventions.

The decrease in rest and routine activity pain during follow-up was statistically siginificant for both groups. Rest and routine activity pain was summarized in Table 2.

Postoperative first day rest pain was increased when compared with preoperative rest pain, and this increase was statistically significant for both groups $(\mathrm{p}$ $=0.003$ for Group 1 and $p<0.001$ for Group 2, Wilcoxon signed rank test). In Group 1 this increase in rest pain was statistically significant for males $(\mathrm{p}<0.001$, Wilcoxon signed rank test), however in females, rest pain also increased but this increase was not statisti- 
Table 1. Arthroscopic interventions and distribution between two groups

\begin{tabular}{|c|c|c|c|}
\hline & Group-1 & Group-2 & P value \\
\hline $\begin{array}{c}\text { Synovectomy } \\
\text { applied/not applied } \\
(\%)\end{array}$ & $87.3 \% / 12.7 \%$ & $78.2 \% / 21.8 \%$ & $0.313^{*}$ \\
\hline $\begin{array}{c}\text { Meniscectomy } \\
\text { applied/not applied } \\
(\%)\end{array}$ & $67.3 \% / 32.7 \%$ & $78.2 \% / 21.8 \%$ & $0.284^{*}$ \\
\hline $\begin{array}{c}\text { Meniscus repair } \\
\text { applied/not applied } \\
(\%)\end{array}$ & $10.9 \% / 89.1 \%$ & $5.5 \% / 94.5 \%$ & $0.489 * *$ \\
\hline $\begin{array}{c}\text { Microfracture } \\
\text { applied/not applied } \\
(\%)\end{array}$ & $14.5 \% / 85.5 \%$ & $12.7 \% / 87.3 \%$ & $1.000^{* *}$ \\
\hline
\end{tabular}

*Chi-Square Continuity Correction.

**Fisher's exact Chi-Square test.

Table 2. Postoperative rest and routine activity pain in follow-up controls

\begin{tabular}{|l|c|c|c|}
\hline \multirow{4}{*}{ Pain } & $\begin{array}{c}\text { Follow-up } \\
\text { control number }\end{array}$ & $\begin{array}{c}\text { Grup-1 } \\
\text { mean (min-max) }\end{array}$ & $\begin{array}{c}\text { Grup-1 } \\
\text { mean (min-max) }\end{array}$ \\
\hline \multirow{4}{*}{ Rest pain } & 1 & $3.55(0-8)$ & $3.05(0-8)$ \\
\cline { 2 - 4 } & 2 & $2.69(0-6)$ & $1.85(0-5)$ \\
\cline { 2 - 4 } & 3 & $2.07(0-6)$ & $1.27(0-5)$ \\
\cline { 2 - 4 } & 4 & $1.78(0-6)$ & $1.09(0-4)$ \\
\hline \multirow{4}{*}{ Activity pain } & P value & $<0.001^{*}$ & $<0.001^{*}$ \\
\cline { 2 - 4 } & 1 & $5.47(2-8)$ & $5.31(1-8)$ \\
\cline { 2 - 4 } & 2 & $4.40(1-7)$ & $3.64(0-7)$ \\
\cline { 2 - 4 } & 3 & $3.55(0-7)$ & $2.76(0-7)$ \\
\cline { 2 - 4 } & 4 & $3.04(0-8)$ & $2.35(0-6)$ \\
\cline { 2 - 4 } & P value & $<0.001^{*}$ & $<0.001^{*}$ \\
\hline
\end{tabular}

min: minimum value, max: maximum value

*Friedman test

cally significant $(\mathrm{p}=0.873$, Wilcoxon signed rank test). In Group 2 rest pain increased for males and females significantly ( $p=0.025$ for males, $p=0.002$ for females, Wilcoxon signed rank test).

Postoperative 15 th day rest pain was compared with preoperative rest pain. In Group 1 no statistically significant difference was found $(\mathrm{p}=0.086$, Wilcoxon Signed Rank test), however in Group 2 postoperative 15 th day rest pain was a statistically lower than preoperative pain ( $\mathrm{p}=0.005$, Wilcoxon Signed Rank test).

Preoperative flexion values were compared with postoperative first and 15th day flexion values in both groups. The first postoperative and 15th day flexion values were decreased when compared with preoperative values and this decrease was statistically significant for both groups $(\mathrm{p}<0.001$ for both groups for all measurements, Wilkinson signed ranks test). However no statistically significant differrence was observed between the groups for flexion decrease $(p=0.474$ and $\mathrm{p}=0.395$ for first and 15 th day follow-up respectively). On the other hand flexion was increased gradually from first postoperative control till last one for both groups ( $p<0.001$ for both groups, Friedman test) final flexion values were reached in last control (3 months) in both groups.

Extension lost was also compared by the same manner between the two groups. Extension lost was seen in postoperative first and 15th day follow-up controls and it was statistically significant for both groups groups ( $p<0.001$ for both groups for all measurements, Wilkinson signed ranks test). Extension loss was not statistically different between the two groups in first and 15th postoperative days $(\mathrm{p}=0.397$ and $\mathrm{p}=$ 0.160 for first and 15 th day follow-up respectively). Extension values were also improved gradually during follow-up period and this increase was statistically sig- 
Table 3. Preoperative (Lysholm-1), postoperative 6th week (Lysholm-2) and postoperative 3rd month (Lysholm-3) Lysholm scores, and preoperative (IKDC-1), postoperative 6th week (IKDC-2) and postoperative $3 \mathrm{rd}$ month (IKDC-3) IKDC scores

\begin{tabular}{|c|c|c|c|}
\hline & $\begin{array}{c}\text { Lysholm-1 } \\
\text { (mean } \pm \text { std. dev. })\end{array}$ & $\begin{array}{c}\text { Lysholm-2 } \\
(\text { mean } \pm \text { std. dev. })\end{array}$ & $\begin{array}{c}\text { Lysholm-3 } \\
\text { (mean } \pm \text { std. dev. })\end{array}$ \\
\hline $\begin{array}{c}\text { Group-1 } \\
(\mathrm{n}=55)\end{array}$ & $57.80 \pm 18.35$ & $67.71 \pm 17.378$ & $75.56 \pm 15.33$ \\
\hline $\begin{array}{l}\text { Group-2 } \\
(\mathrm{n}=55)\end{array}$ & $58.18 \pm 17.598$ & $69.60 \pm 16.186$ & $76.35 \pm 16.463$ \\
\hline
\end{tabular}

\begin{tabular}{|c|c|c|c|}
\hline & $\begin{array}{c}\text { IKDC-1 } \\
\text { (mean } \pm \text { std. dev. })\end{array}$ & $\begin{array}{c}\text { IKDC -2 } \\
\text { (mean } \pm \text { std. dev. })\end{array}$ & $\begin{array}{c}\text { IKDC -3 } \\
\text { (mean } \pm \text { std. dev. })\end{array}$ \\
\hline $\begin{array}{c}\text { Group-1 } \\
(\mathrm{n}=55)\end{array}$ & $54.87 \pm 17.313$ & $63.87 \pm 16.488$ & $71.16 \pm 15.561$ \\
\hline $\begin{array}{c}\text { Group-2 } \\
(\mathrm{n}=55)\end{array}$ & $55.40 \pm 16.346$ & $65.22 \pm 16.582$ & $72.44 \pm 17.427$ \\
\hline
\end{tabular}

std. dev. $=$ Standart deviation

Table 4. Need of puncture for each arthroscopic intervention and comparisons between the two groups

\begin{tabular}{|c|c|c|c|}
\hline & $\begin{array}{c}\text { Group-1 } \\
(\mathrm{n}=55)\end{array}$ & $\begin{array}{c}\text { Group-2 } \\
(\mathrm{n}=55)\end{array}$ & $\begin{array}{c}\text { P value } \\
\text { (for puncture) }\end{array}$ \\
\hline $\begin{array}{c}\text { Synovectomy (\% of total) } \\
/ \text { Puncture (\% in synovectomy) }\end{array}$ & $87.3 \% / 25 \%$ & $78.2 \% / 20.9 \%$ & 1.000 \\
\hline $\begin{array}{c}\text { Meniscectomy (\% of total) } \\
\text { / Puncture (\% in meniscectomy) }\end{array}$ & $67.3 \% / 27 \%$ & $78.2 \% / 23 \%$ & 0.341 \\
\hline $\begin{array}{c}\text { Meniscus repair (\% of total) } \\
\text { / Puncture (\% in meniscus repair) }\end{array}$ & $10.9 \% / 16.7 \%$ & $5.5 \% / 0 \%$ & 1.000 \\
\hline $\begin{array}{c}\text { Microfracture (\% of total) } \\
\text { / Puncture (\% in microfracture) }\end{array}$ & $14.5 \% / 37.5 \%$ & $12.7 \% / 14.2 \%$ & 0.604 \\
\hline
\end{tabular}

nificant for both groups ( $\mathrm{p}<0.001$ for both groups, Friedman test). The patients in Group 1 reached their preopertative extension values in third control (6 weeks), however the patients in Group 2 reached it in second control (second week). Recovery of extension was faster in Group 2.

Preoperative Lysholm and IKDC scores were improved significantly in both groups after operation $(\mathrm{p}<$ 0.001 for both groups and scores). The amount of increase was not statistically different between the two groups $(p=0,735$ for Lysholm and $p=0.729$ for IKDC-repeated measures of ANOVA). Lysholm and IKDC scores were given in Table 3.

Knee puncture was applied to 14 patients in Group 1 and 11 patients in Group 2. Need of puncture was not statistically different between the two groups ( $p=$ 0.649 , continuity to correction). The mean amount of aspirated fluid was $45 \mathrm{cc}(20 \mathrm{cc}-110 \mathrm{cc})$ in Group 1 and $60 \mathrm{cc}(30 \mathrm{cc}-145 \mathrm{cc})$ in Group 2. The amount of fluid which was aspirated from the knee was not also statistically different between the two groups $(p=0.151$, Mann-Whitney U test).
The relationship between the arthroscopic interventions and need of puncture was compared between the two groups. Need of puncture was not statistically different between the groups for synovectomy, meniscectomy, meniscus repair and microfracture $(p=$ $1.000,0.341,1.000$ and 0.604 respectively, Fisher's Exact Chi-Square) (Table 4).

The grade of patellar shock was not statistically different between the two groups in all four postoperative follow-up controls $(p=0.606$ and 1.000 for control one and two respectively, Two Sample Kolmogorov Smirnov test, $p=0.740$ for control three, Continuity to Correction, $p=1.000$ for control four, Fisher's Exact Chi-square).

The patients with and without synovectomy were compared in first and second postoperative controls for patellar shock in Group 1, and no statistically significant difference was found ( $p=1.000$ and $p=0.860$ for controls one and two respectively, Two Sample Kolmogorov Smirnov test). It was no also statistically different in Group 2 ( $p=0.095$ and $p=0.819$ for controls one and two respectively, Two Sample Kolmogorov Smirnov test). 
Table 5. Amount of drainage in Group-1 and its distribution for each arthroscopic intervention

\begin{tabular}{|c|c|c|c|}
\hline & $\begin{array}{c}(+) \\
\text { amount of drainage }(\mathrm{ml}) \\
\text { median (min-max) }\end{array}$ & $\begin{array}{c}(-) \\
\text { amount of drainage }(\mathrm{ml}) \\
\text { median (min-max) }\end{array}$ & $\mathrm{P}^{*}$ \\
\hline Synovectomy & $45(15-250)$ & $40(25-325)$ & $0.970^{*}$ \\
\hline Meniscectomy & $45(15-250)$ & $42.5(20-325)$ & $0.633^{*}$ \\
\hline Meniscus repair & $37.5(30-325)$ & $45(15-250)$ & $0.588^{*}$ \\
\hline Microfracture & $45(25-110)$ & $45(15-325) 0.755^{*}$ & \\
\hline
\end{tabular}

$(+)$ represents the patients with the corresponding intervention (-) represents the patients without corresponding intervention min-max: minimum - maximum

* Mann Whitney U

The same comparisons were also done for patients with meniscectomy and without meniscectomy. No statistical difference was found for both groups in first and second controls $(\mathrm{p}=0.184$ and $\mathrm{p}=0.856$ for Group -1 in first and second controls respectively; $p=0.994$ and $p=$ 0.972 for Group 2 in first and second controls respectively, Two Sample Kolmogorov Smirnov test).

The comparison of patellar shock was not done for microfracture and meniscal repair due to small number of patient population.

The patients with synovectomy and without synovectomy in Group-1 were compared for the amount of drainage. The same comparison was also done for meniscectomy, meniscal repair and microfracture. The amount of fluid was not statistically different for all arthroscopic interventions in Group 1 (Table 5).

The patients with synovectomy were compared for patellar shock between the two groups. No statistically significant difference was found between the two groups in all four follow-up controls $(\mathrm{p}=0.765$ and $\mathrm{p}=$ 0.999 for controls one and two, Two Sample Kolmogorov Smirnov test, $\mathrm{p}=0.717$ and $\mathrm{p}=1.000$ for control three and four, Fisher's Exact Chi-square). Need for knee puncture ( $p=0.833$, Continuity to Correction) and amount of fluid from knee puncture ( $p=0.114$, Mann Whitney U test) were not also statistically different between the two groups in patients with synovectomy.

The patients with meniscectomy were compared for patellar shock between the two groups. No statistically significant difference was found between the two groups in all four follow-up controls $(\mathrm{p}=0.990$ and $\mathrm{p}=$ 1.000 for controls one and two, Two Sample Kolmogorov Smirnov test, 1.000 and $p=0.462$ for control three and four, Fisher's Exact Chi-square). Need for knee puncture ( $\mathrm{p}=0.987$, Continuity to Correction) and amount of fluid from knee puncture $(\mathrm{p}=0.149$, Mann Whitney U test) were not also statistically different between the two groups in patients with meniscectomy.

Type of anesthesia (spinal block or general anesthesia) and the amount of drainage fluid were compared and no statistically significant difference was found ( $p$ $=0.867$, Mann Whitney U).

Time of hospitalization was not statistically different between Group 1 (4.02 \pm 2.649 days) and Group 2 (3.18 \pm 1.906 days) $(\mathrm{p}=0.132$ Mann Whitney U test $)$.

Time to return occupation was $20.36 \pm 13.012$ days for Group 1 and $18.15 \pm 11.715$ days fro Group 2. There was not a statistically significant difference between the two groups ( $p=0.310$, Mann Whitney U test).

\section{DISCUSSION}

According to our hypothesis suction drain usage after arthroscopic knee surgery decreases postoperative hemarthrosis and subsequent knee effusion and increases postoperative comfort. This hypothesis was refused after this investigation.

Suction drains are useful in drainage of hematoma or fluid from cavitary regions (4). During knee arthroscopy some surgical interventions like synovectomy or meniscectomy may lead to bleeding and hemarthrosis $(2,8,9)$. Hemarthrosis may irritate synovium and may stretch joint capsule causing to postoperative pain (1). Postoperative pain is one of the most important parameters decreasing patient complience to postoperative rehabilitation, therefore may alter recovery (4). In theory suction drains can decrease the formation of hemarthrosis and indirectly may affect recovery. This study was designed to investigate the benefits of suction drain application after arthroscopic knee surgery.

Rest pain and routine activity pain were both decreased statistically after the operation in both groups. This result was an indicator of patient recovery after the operation.

Postoperative first day rest pain was statistically increased in both groups when compared with preoperative rest pain. Increased rest pain was observed in both groups, therefore it was thought that increase in pain was not related with suction drain usage. This pain increase was interpreted as postoperative surgical pain. 
In control group post operative rest pain increase did not differ between the two sex. However, in suction drain group postoperative first day rest pain increase was observed in males but it was not observed in females. It can be thought that females might be more tolerable for drain usage.

Postoperative 15 th day rest pain was compared with preoperative rest pain to evaluate the relief of surgical pain. In suction drain group no statistical difference was found between the preoperative and postoperative 15 th day rest pain. However, in control group, postoperative 15 th day rest pain was statistically lower than preoperative rest pain. Therefore it was thought that, suction drain usage after knee arthroscopy may delay the recovery of postoperative pain.

Some amount of flexion - extension loss is expected after arthroscopic knee surgery during the early postoperative period due to hemarthrosis, edema and postoperative pain (10). Flexion and extension values of both groups were compared to evaluate the effect of suction drain inpostoperative loss of range of motion.

When postoperative 1 st and 15 th day flexion degrees were compared with preoperative flexion values, a statistically significant decrease was observed in both groups. This loss in flexion values was an expected finding. Postoperative loss of flexion was not statistically different for both groups, therefore it was thought that, loss of flexion during the early postoperative period was not related with suction drain usage. Flexion values were increased gradually during the follow-up period and preoperative flexion values were reached in the last control (postoperative 3rd month) in both groups. It was thought that recovery of flexion values during the postoperative period was not affected by suction drain usage in this study.

Extension loss was also observed in both groups postoperatively, however it was not statistically different between the two groups. Therefore it was thought that, loss of extension in the early postoperative period was due to postoperative changes. Extension values were also improved gradually during the postoperative period, and this improvement was not statistically different between the two groups. Preoperative extention values were obtained in second week control in control group, and in 6th week in suction drain group. Preoperative extension values were reached in both groups, however this recovery of extension was faster in control group. Therefore it can be thought that, suction drain usage may delay recovery of extension after arthroscopic knee surgery.

When the scoring systems were evaluated it was observed that both IKDC and Lysholm scores were improved statistically in both groups. Improvement in IKDC and Lysholm scores were not statistically differ- ent between the two groups. According to these results, it was observed that, the pain of the patients was decreased, and quality of life was increased after arthroscopic knee surgery, however suction drain usage did not affect these results.

Knee hemarthrosis is one of the most commonly seen complications after knee arthroscopy (11). Occasionally hemarthrosis stretches the joint capsule leading to pain and tenderness and it decreases patient compliance to postoperative rehabilitation (1). When hemarthrosis is observed in the postoperative period a knee puncture may be needed to drain the knee. In this study 25 patients needed knee puncture. Need of knee puncture was not statistically different between the two groups, therefore using suction drains did not decrease the need of knee puncture in this study. The amount of aspirated fluid was also measured and compared between the two groups. The amount of aspirate was not also statistically different between the two groups. Therefore, usage of suction drains after knee arthroscopy did not improve the need of knee puncture and did not decrease the amount of aspirate material in this study.

Some interventions during arthroscopic knee surgery may cause more bleeding than the others like synovectomy and microfracture (11). In these synovectomy and microfracture patients, more bleeding is expected after the operation, which increases the need of knee puncture due to hemarthrosis. Need of knee puncture and the effect of suction drain usage were investigated for each arthroscopic procedure in the study. The relationship between the arthroscopic interventions and need of puncture was compared between the two groups. Need of puncture was not statistically different between the groups for synovectomy, meniscectomy, meniscus repair and microfracture. It was observed that, suction drain usage did not decrease the need of postoperative knee puncture even in synovectomy and microfracture patients where much bleeding is expected.

Patellar shock is a valuable finding in the follow-up of postoperative knee effusion. Both groups were investigated for the development of patellar shock during the follow-up periods. Patellar shock was not statistically different between the two groups in all four postoperative follow-up controls. Using postoperative suction drain did not affect the development of patellar shock in this study.

Patellar shock is an important finding of early postoperative hemarthrosis after arthroscopic knee surgery (7). Synovial tissue is a vascular tissue, therefore after synovectomy postoperative patellar shock is expected due to increased bleeding $(1,11)$. Using a suction drain after synovectomy may decrease the amount of patellar shock theoretically. The patients with and without synovectomy in Group 1 were compared for 
patellar shock in first and second postoperative controls to investigate the benefits of suction drain usage in synovectomy patients. However no statistically significant difference was observed for patellar shock in first and second controls between the patients with synovectomy and without synovectomy. The same comparisons were also done for Group 2 and no statistically significant difference was observed. According to these results it was thought that, synovectomy did not increase the risk of hemarthrosis and patellar shock development alone. It was thought that, causes of knee hemarthrosis after synovectomy must be investigated with further studies. It was also observed that suction drain usage did not decrease the hemarthrosis after arthroscopic synovectomy. As a result it was concluded that, using suction drain after arthroscopic synovectomy to decrease the amount of hemarthrosis is an invaluable procedure.

The same comparisons about patellar shock were also done for patients with meniscectomy and without meniscectomy. No statistical difference was found between the patients with meniscectomy and without meniscectomy for both groups in first and second controls. It was also concluded that using suction drain after arthroscopic meniscectomy to decrease the amount of hemarthrosis is an invaluable procedure.

The amount of drainage fluid in the suction drain was measured in the patient Group 1. This drainage was composed of blood in all cases, therefore it is used as a measurement of early postoperative bleeding. The patients with synovectomy and without synovectomy in Group 1 were compared for the amount of drainage. The same comparison was also done for meniscectomy, meniscal repair and microfracture. The amount of fluid was not statistically different for all arthroscopic interventions in Group 1. It was thought that, the amount of drainage was not directly related with arthroscopic intervention. However such a result may not be correct since, more than one interventions were applied to all patients during arthroscopy. This is one of the weak points of this study.

The patients with synovectomy in two groups were compared for patellar shock. No statistically significant difference was found between the two groups in all four follow-up controls. The same comparisons were also done for need of knee puncture and amount of fluid which was aspirated during knee puncture. Need for knee puncture and the amount of fluid from knee puncture were not also statistically different between the two groups in patients with synovectomy. Therefore it was thought that using suction drain after arthroscopic knee surgery did not affect patellar shock development, need of knee puncture and the amount of fluid from knee puncture after arthroscopic synovectomy.
The patients with meniscectomy in two groups were also compared for the parameters above. No statistically significant difference was found between the two groups in all four follow-up controls for the development of patellar shock. Need for knee puncture and amount of fluid from knee puncture were not also statistically different between the two groups in patients with meniscectomy. Therefore it was thought that using suction drain after arthroscopic knee surgery did not affect patellar shock development, need of knee puncture and the amount of fluid from knee puncture after arthroscopic meniscectomy.

As a result, it was thought that, development of postoperative knee effusion (hemarthrosis) after arthroscopic meniscectomy and synovectomy was independent of suction drain usage.

There are three meta analysis in the literature about the comparison of general and regional anesthesia in knee and hip surgery $(12,13,14)$. Although there is a marked heterogenity about peroperative blood loss and need of blood transfusion, there is a tendency of increased blood loss in general anesthesia. The effect of anesthesia on bleeding after arthroscopic knee surgery was also investigated in this study. The amount of drainage fluid from suction drain was compared between the patients who had spinal or general anesthesia. There was no statistically significant difference between the two anesthesia types for the amount of drainage. Therefore it can be suggested that early postoperative hemorrhage after arthroscopic knee surgery is not related with the type of anesthesia in this study.

Hospitalization time was not statistically different between the two groups. The patients with suction drain did not discharge early from the hospital. The time from the operation till return to occupation was also compared between the two groups and again no statistical difference was observed. Loss of labor did not decrease after the usage of suction drains.

\section{Limitations}

Statistical comparisons cannot be done for meniscal repair and microfracture subgroups due to small sample size to evaluate the risk of hemarthrosis. Further studies with much larger series are needed development after arthroscopic meniscal repair and microfracture.

More than one arthroscopic intervention was applied to all patints, therefore generalizing the results for a single intervention might cause bias. For more precise results the observations must be performed after a single arthroscopic intervention, but randomization of these patients is not possible, since decision making is done during the operation in arthroscopy. The preoperative diagnosis may change during arthro- 
scopy, additional pathologies can be observed, and preoperative plan can be changed according to these new findings.

\section{CONCLUSION}

We do not suggest routine usage of a suction drain after arthroscopic knee surgery. Although recovery of extension loss was faster in the control group, preoperative flexion and extension values were obtained in both groups in the last follow up. Although suction drain usage delayed the recovery of postoperative pain in this study other parameters of pain were not affected from suction drain usage. It can be used selectively in patients with high risk of bleeding like total arthroscopic synovectomy.

\section{Acknowledgements}

This subject was graduation thesis of Dr. Cüneyt Öncel (one of our residents in Trakya University, Edir- ne, Turkey) and preliminary results were reported as graduation thesis (about a total of 70 patients). The study was finished by us and a manuscript was prepared. These preliminary results were also reported in the XXIIth National Turkish Orthopedics and Traumatology Congress in 2011 Antalya, TURKEY as an oral presentation. Dr Nurhak Yavuz was also helped in data collection for this research. We confirm that, this manuscript is original and has not been submitted elsewhere for publication or has been published elsewhere.

\section{DECLARATION OF INTEREST}

The autors declare that there are no conflicts of interests.

\section{Licensing}

This work is licensed under a Creative Commons Attribution 4.0 International (CC BY 4.0) License.

\title{
Sažetak
}

\section{EFIKASNOST PRIMENE DRENAŽE U ARTROSKOPSKOJ OPERACIJI KOLENA}

\author{
Oncel Cuneyt, ${ }^{1}$ Ozcan Mert, ${ }^{2}$ Erem Murat, ${ }^{2}$ Copuroglu Cem, ${ }^{2}$ \\ Ciftdemir Mert, ${ }^{2}$ Turan Nesrin Fatma \\ ${ }^{1}$ Yücelen Hospital, Department of Orthopaedic Surgery and Traumatology, Muğla, Turkey \\ 2 Trakya University, Medical Faculty, Department of Orthopaedic Surgery and Traumatology, Edirne, Turkey \\ ${ }^{3}$ Trakya University, Medical Faculty, Department of Biostatistics, Edirne, Turkey
}

Cilj: Cilj ove studije bio je da se ispita efikasnost sukcionog drena nakon artoskopske operacije kolena. Hipotetički govoreći, pošli smo od pretpostavke da sukcioni dren smanjuje postoperativnu hemartrozu nakon artroskopske operacije kolena.

Metode: Pacijenti su nasumično podeljeni u dve grupe. U Grupi I korišćen je sukcioni dren, a u Grupi II nije korišćena sukciona drenaža postoperativno. Grupe su poređene u pogledu oporavka, bolova pri pokretima, opsega pokreta, prema tablicama Lisholma i internacionalnog saveta za dokumetaciju o operacijama kolena (IKDC), patelarnog stresa, potrebe za postoperativnom punkcijom kolena, količine dreniranog sadržaja, vremena provedenog u hospitalizaciji i gubitka radne snage obolelog kolena. Artroskopske intervencije koje su bile korišćene uključivale su meniscektomiju, sinoviektomiju, popravku meniskusa i mikrofrakture. Ove intervencije su takođe bile upoređivane u pogledu ukupnog stresa po patelu, potrebe za postoperativnom drenažom i količine dreniranog sadržaja.

Rezultati: Nije nađena statistički značajna razlika $\mathrm{u}$ pogledu postoperativnog bola $\mathrm{i}$ opsega pokreta $\mathrm{u}$ zglobu kolena između grupa. Parametar - bol u mirovanju je značajno brže zaceljivao u kontrolnoj grupi. Lisholm vrednosti skorova I IKDS skor su značajno bili bolji u obe grupe, ali brzina porasta nije bila od statističke značajnosti. Statistička značajnost u pogledu parametra - količina patelarnog stresa takođe nije bila od statističke značajnosti među grupama. Stepen patelarnog stresa, potreba za postoperativnom punkcijom kolena i količina dreniranog sadržaja nisu bili statistički značajni za artroskopske intervencije kao što su meniscektomija i sinoviektomija.

Zaključak: Primena sukcionog drena bila je nepotrebna u mnogim slučajevima nakon artoskopske operacije kolena u ovoj studiji. Iako je primena sukcione drenaže imala za posledicu duži period oporavka od postoperativnog bola, drugi parametri bola nisu bili uzrokovani primenom sukcionog drena. Prema rezultatima ove studije, rutinsko korišćenje sukcionog drena nakon artroskopske operacije kolena se ne preporučuje.

Ključne reči: sukciona drenaža, artroskopija kolena, hemartroza, postoperativni bol, patelarni stres. 


\section{REFERENCES}

1. Akan K, Ünay L, Berkem L, Güven M, Poyan12 O. Suction drainage influence on knee effusion following partial fat pad or synovium resection. Acta Orthop Traumatol Turc. 2001; 45(4): 221-4.

2. Coupens SD, Yates CK. The effect of tourniquet use and hemovac drainage on postoperative hemarthrosis. Arthroscopy. 1991; 7(3): 278-82doi:10.1016/0749-8063(91)90127-J.

3. Tatari H, Dervi bey M, Murat12 K, Ergör A. Report of experience in 190 patients with the use of closed suction drainage in arthroscopic knee procedures. Knee Surg Sports Traumatol Arthrosc. 2005; 13(6): 458-62.

4. Browett JP, Gibbs AN, Copeland SA, Deliss Lj. The use of suction drainage in the operation of meniscectomy. J Bone Joint Surg. 1978; 60-B(4): 516-9.

5. Lysholm J, Gillquist J. Evaluation of knee ligament surgery results with special emphasis on use of a scoring scale. Am J Sports Med. 1982; 10(3): 150-4.

6. Anderson AF, Irrgang JJ, Kocher MS, Mann BJ, Harrast JJ. International Knee Documentation Committee. The International knee documentation committee subjective knee evaluation form: normative data. Am J Sports Med. 2006; 34(1): 128-35.
7. Nett MP, Pedersen HB, Roehring GJ, Tria AJ, Scott WN. Clinical examination of the knee. In: Scott WN, ed. Surgery of the Knee. Philadelphia: Elsevier, 2012; 47-60.

8. Clifton R, Haleem S, McKee A, Parker MJ. Closed suction surgical wound drainage after anterior cruciate ligament reconstruction: a systemic review of randomised controlled trials. Knee. 2007; 14: 348-51.

9. Johnson LL. Characteristics of the immediate postarthroscopic blood cloth formation in the knee joint. Arthroscopy. 1991; 7(1): 14-23.

10. Kissin YD, Scott WN, Cushner FD. Arthroscopic meniscal resection. In: Scott WN, ed. Surgery of the Knee. Philadelphia: Elsevier, 2012; 268-74.

11. Monchik K, Fadale P. Arthroscopic approaches to synovial pathology. In: Johnson DH, ed. Operative Arthroscopy. Philadelphia: Lippincott, 2013; 923-31.

12. Sorenson RM, Pace NL. Anesthetic techniques during surgical repair of femoral neck fractures. A meta analysis. Anesthesiology. 1992; 77(6): 1095-104.

13. Hu S, Zhang ZY, Hua YQ, Li J, Cai ZD. A comparison of regional and general anesthesia for total replacement of the hip or knee. A meta analysis. J Bone Joint Surg (Br). 2009; 91(7): 935-42.

14. Urwin SC, Parker MJ, Griffiths R. General versus regional anaesthesia for hip fracture surgery. A meta analysis of randomized trials. Br J Anesthes. 2000; 84(4): 450-5.

\section{Correspondence to/Autor za korespondenciju}

Mert Özcan, MD, Assoc. Prof.

Trakya Universitesi Tip Fakultesi Ortopedi ve Travmatoloji AD,

Edirne, Turkey

Telephone: +905334144819

Fax: +902842233314

e-mail: mertozcan@trakya.edu.tr 